RESEARCH ARTICLE

Nilufer Emre ${ }^{1}$

(D) Tugba Sari ${ }^{2}$

${ }^{1}$ Department of Family

Medicine, Pamukkale

University School of

Medicine, Denizli, Turkey

${ }^{2}$ Department of Infectious

Diseases and Clinical

Microbiology, Pamukkale

University School of

Medicine, Denizli, Turkey

Corresponding Author:

Nilufer Emre

Department of Family Medicine,

Pamukkale University School of

Medicine, Denizli, Turkey

mail: nilemre83@gmail.com

Phone: +90258 2961655

Received: 11.08 .2020

Acceptance: 28.01 .2021

DOI: $10.18521 / \mathrm{ktd} .779179$

Konuralp Medical Journal e-ISSN1309-3878

konuralptipdergi@duzce.edu.tr konuralptipdergisi@gmail.com www.konuralptipdergi.duzce.edu.tr

\section{Evaluation of the Behavior, Anxiety and Stress of University Students in the New Type of Coronavirus Pandemic ABSTRACT}

Objective: Acute respiratory disease called COVID-19 caused by SARS-CoV-2 caused a pandemic affecting the whole world. Our aim in this study is to evaluate the cleaning behaviors and social behaviors, anxiety and stress situations of university students caused by COVID-19 pandemic.

Methods: At the beginning of Covid-19 pandemic; university students were asked questions about their socio-demographic characteristics, their cleaning and social habits, and their level of stress about being infected for themselves and their family members and also a questionnaire was applied which includes a generalized anxiety disorder scale to measure anxiety levels and Impact of Events Scale (IES) to assessing traumatic stress symptoms.

Results: It was observed that hand washing behavior increased in $62.4 \%$ of 463 participants. The mean of the students' generalized anxiety score was determined as 3.86 \pm 4.86 and $17.5 \%(\mathrm{n}=81)$ of all students had high anxiety. The mean scores of the impact of event scale were $14.23 \pm 10.9$ and stress points average was found as $5.57 \pm 2.9$. Students' stress and anxiety affect their cleaning and social behaviors. In addition, when compared between student groups, anxiety, stress, and the IES and subscales were found to be significantly higher in female students and also in students of faculties other than medical students.

Conclusions: The state of anxiety and stress caused by pandemics affecting the whole world on people affects society and human behavior. At the beginning of the Covid 19 pandemic, an increase is observed in university students, especially in handwashing. In addition, other student groups other than medical students and female students are more affected by anxiety, stress and events.

Keywords: Coronavirus, Outbreaks, Student, Anxiety

\section{Üniversite Öğrencilerinde Yeni Tip Corona Virus Pandemisinde Davranış, Kaygı Ve Stress Durumunun Değerlendirmesi \\ ÖZET}

Amaç: SARS-CoV-2'nin neden olduğu COVID-19 olarak adlandırılan akut solunum yolu hastalığ tüm Dünya'yı etkileyen pandemiye neden olmuştur. Bu çalışmadaki amacımız üniversite öğrencilerinin COVID-19 pandemisi nedeniyle oluşan temizlik ve toplumsal davranışlarını, kaygı ve stress durumlarını değerlendirmektir.

Gereç ve Yöntem: Covid-19 pandemisi başlangıcında; üniversite öğrencilerine sosyodemografik özellikler, temizlik ve toplumsal alışkanlıklar, kendisine ve aile üyelerine bulaşmasıyla ilgili endişe düzeyini sorgulayan sorular ve kaygı düzeyleri ölçmek için Yaygın Anksiyete Bozukluğu Ölçeği ve stres durumlarını ölçen Olayların Etkisi Ölçeği'ni içeren anket uygulandı.

Bulgular: 463 katılımcıdan, \%62,4'ünde el yıkama davranışının arttığı gözlendi. Öğrencilerin yaygın anksiyete puanı ortalaması $3,86 \pm 4,86$ ve tüm öğrencilerin $\% 17,5^{\prime}$ inde $(\mathrm{n}=81)$ yüksek düzeyde anksiyete mevcuttu. Olay etki ölçeği puan ortalamaları $14,23 \pm 10,9$ ve endişe puanları ortalaması 5,57 $\pm 2,9$. Öğrencilerin anksiyete ve endişeleri temizlik ve toplumsal davranışlarını etkilemektedir. Ayrıca öğrenci grupları arasında karşılaştırıldığında anksiyete, endişe ve olay etki ölçeği ve alt ölçekleri kız öğrencilerde ve tıp fakültesi öğrencilerine göre diğer fakülte öğrencilerinde anlamlı düzeyde daha fazla bulundu.

Sonuç: Tüm Dünya'y1 etkileyen pandemilerin insanlar üzerinde yarattı̆̆ anksiyete ve endişe durumu, toplumu ve insan davranışlarını etkilemektedir. Covid 19 pandemisinin başlangıcında da üniversite öğrencilerinde özellikle el yıkama davranışında artış gözlenmektedir. Ayrıca tıp öğrencileri dışındaki diğer öğrenci gruplarında ve kız öğrencilerde daha fazla anksiyete, stres ve olaydan etkilenme yaşamaktadırlar.

Anahtar Kelimeler: Coronavirüs, Salgın, Öğrenci, Anksiyete 


\section{INTRODUCTION}

SARS-CoV-2, which causes the acute respiratory disease called COVID-19, is a new betacoronavirus. It first emerged on December 31, 2019 as a new acute respiratory infection disease of unknown etiology in Wuhan, Hubei Province, China. On January 30, 2020, the World Health Organization (WHO) declared the disease as an Internationally Important Public Health Emergency and on March 11, 2020 as a pandemic (1-3). The first confirmed COVID-19 case in Turkey was reported on March 11, 2020. With the COVID-19 pandemic, a rapid transformation and adaptation process began in the healthcare system and education system in many regions of the world and in Turkey. In order to prevent the spread of COVID-19 in our country, education was suspended in primary, secondary, and higher education as of March 16, 2020. Education at universities was moved online rather than face-toface, and changes were made to educational processes in university institutions (4). In addition, life and work plans changed with the outbreak, and long-term home isolation further increased the levels of mental stress and anxiety in most university students (5).

Studies have shown that the number of people reporting mental health and psychosocial problems increases significantly during outbreaks (6). In addition to posing serious threats to the physical health of vulnerable people, emerging infectious diseases and large-scale outbreaks may worsen negative effects on mental health such as anxiety, depression, and other negative emotions, and they may even cause psychological crises (5). In addition, social behaviors of students change during the pandemic process. Studies show that behaviors that prevent infection, such as handwashing, are becoming more common during the pandemic $(7,8)$.

Research shows that public health emergencies creates many psychological effects, such as fear and anxiety, and behavioral changes in university students (9). Our aim in this study is to evaluate the cleaning behaviors and social behaviors, anxiety and stress situations of university students during the coronavirus pandemic.

\section{MATERIAL AND METHODS}

A cross-sectional survey was designed to assess students' cleaning and social behavior, stress, and anxiety during the COVID-19 outbreak. The study was approved by the ethics committee of the Pamukkale University Clinical Research Ethics Commission.. It was conducted between March 3, 2020 and April 30, 2020, that is, it started in the period when COVID-19 cases were not yet detected in our country and ended when the cases started to emerge.

A face-to-face questionnaire was conducted. The students participating in the study were asked in the first part, which was six questions, about cleaning and social behaviors, along with sociodemographic features (age, gender, university department), and they were asked to score their level of stress about coronavirus infecting them and their family members between 1 and 10 . In the second part, the generalized anxiety disorder scale was used to measure students' anxiety. In the third part, the Impact of Events Scale (IES) was used to measure post-traumatic stress levels.

Generalized Anxiety Disorder Scale: A seven-item, four-point Likert-type generalized anxiety disorder scale was used to evaluate the generalized anxiety disorder developed by Spitzer et al. This scale is a self-report scale with Turkish validity and reliability performed by Konkan et al. In the YAB-7 Turkish form, the most acceptable cutoff value for specificity and sensitivity was determined to be 8 . This cutoff value was used in our study (10).

The Impact of Events Scale (IES): The IES is a five-point Likert-type scale composed of 22 items developed by Horowitz, Wilner, and Alvarez (1979) and whose validity and reliability in Turkish was performed by Çorapoğlu, Yargıç, Geyran, Kocabaşoğlu (2006). The scale has three subscales: 'Intrusion', 'Avoidance', and 'Hyperarousal'. The lowest score on the scale is 0 , and the highest score is 88 . The total score of the scale is calculated by adding up the scores obtained from each item. A high score indicates that the respondent is more affected by a negative life event, and a low score indicates that the respondent is less exposed to a negative life event (11).

\section{RESULTS}

The study included 463 students. The mean age of the students was $21.86 \pm 1.96$. Of the total number of students, $67 \%$ were female students. The majority of students $(n=349)$ stated that they received information about the coronavirus from social media. Table 1 presents the demographic characteristics of students and their sources of information about the coronavirus.

Table 1. Students' demographic characteristics and sources of information about corona virüs

\begin{tabular}{lll}
\hline \multicolumn{1}{c}{ Variables } & $\mathrm{n} / \mathrm{mean}$ & $\%$ \\
\hline Age & $21.56 \pm 1.96$ & \\
\hline Gender & & \\
Female & 310 & 67.0 \\
Male & 153 & 33.0 \\
\hline Students' department & & \\
Medical student & 257 & 55.5 \\
Health student & 132 & 28.5 \\
Other student & 74 & 16.0 \\
\hline Information Sources* & & \\
Ministry statements & 209 & 45.1 \\
Ministry websites & 69 & 14.9 \\
WHO & 79 & 17.1 \\
Other websites & 144 & 31.1 \\
Health institutions & 110 & 23.8 \\
Tv /newspaper & 251 & 54.2 \\
Social media/internet & 349 & 75.4 \\
Families and friends & 199 & 43.0 \\
\hline$*$ Multiple options are marked & & \\
& &
\end{tabular}


When students were asked about changes in cleaning and social behaviors after the coronavirus started to be seen in China, it was determined that handwashing behavior increased in $62.4 \%$ of students, handshakes decreased in $34.4 \%$, and presence in crowded environments decreased in $33.0 \%$. Table 2 presents the findings of the answers about students' cleaning and social behaviors The mean of the students' generalized anxiety score was determined to be $3.86 \pm 4.86$, and $17.5 \%(n=81)$ of all students had high anxiety. The mean scores of the IES were $14.23 \pm 10.9$ and rate of intrusion the subscales was $6,89 \pm 4.41$. Avoidance was $2.89 \pm$ 3.9 and hyperarousal was $2.89 \pm 3.9$.

Table 2. Changes in students' cleaning and social habits

\begin{tabular}{|c|c|c|c|c|c|c|}
\hline & \multicolumn{2}{|c|}{ Unchanged } & \multicolumn{2}{|c|}{ Slightly increased } & \multicolumn{2}{|c|}{ İncreased a lot } \\
\hline & $\mathrm{n}$ & $\%$ & & $\%$ & $\mathrm{n}$ & $\%$ \\
\hline Washing hands & 174 & 37.6 & 227 & 49.0 & 62 & 13.4 \\
\hline Buying cleaning supplies & 361 & 78.0 & 89 & 19.2 & 13 & 2.8 \\
\hline \multirow[t]{3}{*}{ Avoiding contact with people } & 195 & 42.1 & 183 & 39.5 & 85 & 18.4 \\
\hline & \multicolumn{2}{|c|}{ Unchanged } & \multicolumn{2}{|c|}{ Slightly decreased } & \multicolumn{2}{|c|}{ Decreased a lot } \\
\hline & $\mathrm{n}$ & $\%$ & & $\%$ & $\mathrm{n}$ & $\%$ \\
\hline Handshake & 304 & 65.7 & 148 & 32.0 & 11 & 2.4 \\
\hline Being in crowded environments & 310 & 67.0 & 147 & 31.7 & 6 & 1.3 \\
\hline Frequency of purchasing products from China & 278 & 60.0 & 158 & 34.1 & 27 & 5.8 \\
\hline
\end{tabular}

When student groups were compared, anxiety, stress, the impact of the event, intrusion, and hyperarousal were statistically significantly lower in medical students than other health students and students from other departments $(\mathrm{p}=0.044 ; \mathrm{p}=$ $0.002 ; \mathrm{p}=0.001 ; \mathrm{p}=0,0001 ; \mathrm{p}=0,0001$ respectively). When compared in terms of gender, anxiety, stress, the impact of the event, and subscale scores were significantly higher in girls than in boys $(\mathrm{p}=0,0001 ; \mathrm{p}=0,0001 ; \mathrm{p}=0,0001 ; \mathrm{p}$ $=0,0001 ; \mathrm{p}=0,0001 ; \mathrm{p}=0,0001$, respectively $)$, (Table 3).

Table 3. Assessment of students' anxiety, impact of the event and stress scores

\begin{tabular}{|c|c|c|c|c|c|c|}
\hline & $\begin{array}{l}\text { Anxiety } \\
\text { score }\end{array}$ & $\begin{array}{l}\text { İmpact of event } \\
\text { score }\end{array}$ & $\begin{array}{l}\text { Intrusion } \\
\text { score }\end{array}$ & $\begin{array}{l}\text { Avoidance } \\
\text { score }\end{array}$ & $\begin{array}{l}\text { Hyperarousal } \\
\text { score }\end{array}$ & $\begin{array}{l}\text { Stress } \\
\text { score }\end{array}$ \\
\hline \multicolumn{7}{|l|}{ Gender } \\
\hline Female & $4.42 \pm 5.06$ & $15.29 \pm 10.47$ & $4.85 \pm 4.45$ & $7.13 \pm 4.15$ & $3.27 \pm 4.03$ & $6.05 \pm 2.89$ \\
\hline Male & $2.73 \pm 4.22$ & $12.09 \pm 11.63$ & $3.54 \pm 4.71$ & $6.39 \pm 4.84$ & $2.13 \pm 3.58$ & $4.58 \pm 2.96$ \\
\hline $\begin{array}{l}\text { Statistics }^{a} \\
P\end{array}$ & $\begin{array}{l}z=-4.278 \\
p=0.0001\end{array}$ & $\begin{array}{l}z=-4.503 \\
p=0.0001\end{array}$ & $\begin{array}{l}z=-2.408 \\
p=0.16\end{array}$ & $\begin{array}{l}z=-4.408 \\
p=0.0001\end{array}$ & $\begin{array}{l}z=-4.210 p= \\
0.0001\end{array}$ & $\begin{array}{l}z=-4.952 \\
p=0.0001\end{array}$ \\
\hline \multicolumn{7}{|l|}{$\begin{array}{l}\text { Students' } \\
\text { department }\end{array}$} \\
\hline Medical student & $3.43 \pm 4.51$ & $12.94 \pm 10.39$ & $3.84 \pm 4.59$ & $6.64 \pm 4.25$ & $2.44 \pm 3.55$ & $5.19 \pm 2.88$ \\
\hline Health student & $4.44 \pm 5.43$ & $14.99 \pm 11.55$ & $4.92 \pm 4.64$ & $6.87 \pm 4.76$ & $3.14 \pm 4.03$ & $5.75 \pm 3.12$ \\
\hline Other student & $4.32 \pm 4.91$ & $17.38 \pm 11.19$ & $5.53 \pm 4.10$ & $7.76 \pm 4.10$ & $4.05 \pm 4.68$ & $6.54 \pm 2.90$ \\
\hline $\begin{array}{l}\text { Statistics }^{b} \\
P\end{array}$ & $\begin{array}{l}6.259 \\
P=0.044\end{array}$ & $\begin{array}{l}13.777 \\
P=0.001\end{array}$ & $\begin{array}{l}21.048 \\
P=0.0001\end{array}$ & $\begin{array}{l}5.086 \\
P=0.079\end{array}$ & $\begin{array}{l}15.497 \\
P=0.0001\end{array}$ & $\begin{array}{l}12.16 \\
P=0.002\end{array}$ \\
\hline
\end{tabular}

${ }^{\mathrm{a}}$ Significance of difference determined using Mann Whithey $\mathrm{U}$

${ }^{\mathrm{b}}$ Significance of difference determined using Kruskal walls

Table 4 shows the relationship between the cleaning and social behaviors of the students and anxiety, stress, and the impact of the event. It is observed that as students' anxiety, stress, and being affected by the event increase, handwashing behavior, cleaning equipment and avoiding contact with others increases and handshaking behavior decreases. In addition, anxiety, stress, and the impact of the event show a positive relationship with each other.

\section{DISCUSSION}

In this study, which began before COVID19 cases were seen in Turkey and ended after a few cases emerged, high levels of anxiety were observed in $17.5 \%$ of university students. In studies conducted with university students in different parts of China, anxiety rates were found to be $7.7 \%-$ $24.9 \%(5,12)$. In an anxiety evaluation of nursing students in Israel, which was performed in the third week of the quarantine process, moderate anxiety was found in $42.8 \%$ and severe anxiety in $13.1 \%$ of the students (13). Anxiety was more common in female students and in students studying discplines other than medicine. In studies conducted during the outbreaks of MERS-CoV and SARS, which have similar transmission pathways, it was reported that more anxiety was observed in female students in both health and non-health areas (14-16). It was observed that high levels of anxiety were caused by the stress students experienced over whether they or 
Table 4 The relationship between students' behavior, anxiety, stress and impact of event

\begin{tabular}{|c|c|c|c|c|c|c|c|c|c|c|}
\hline & & (A) & (B) & (C) & (D) & (E) & $(\mathrm{F})$ & (G) & $(\mathrm{H})$ & (I) \\
\hline $\begin{array}{l}\text { Anxiety } \\
\text { (A) }\end{array}$ & $\begin{array}{l}r \\
p\end{array}$ & & & & & & & & & \\
\hline $\begin{array}{l}\text { Stress } \\
\text { (B) }\end{array}$ & $r$ & $\begin{array}{l}.308 \\
.000 \\
\end{array}$ & & & & & & & & \\
\hline $\begin{array}{l}\text { impact of event } \\
\text { (C) }\end{array}$ & $r$ & $\begin{array}{l}.548 \\
.000\end{array}$ & $\begin{array}{l}.394 \\
.000\end{array}$ & & & & & & & \\
\hline $\begin{array}{l}\text { Intrusion } \\
\text { (D) }\end{array}$ & $r$ & $\begin{array}{l}.499 \\
.000 \\
\end{array}$ & $\begin{array}{l}.428 \\
.000\end{array}$ & $\begin{array}{l}.833 \\
.000\end{array}$ & & & & & & \\
\hline $\begin{array}{l}\text { Avoidance } \\
(\mathrm{E})\end{array}$ & $\begin{array}{l}r \\
p\end{array}$ & $\begin{array}{l}.312 \\
.000 \\
\end{array}$ & $\begin{array}{l}.202 \\
.000 \\
\end{array}$ & $\begin{array}{l}.808 \\
.000 \\
\end{array}$ & $\begin{array}{l}.462 \\
.000 \\
\end{array}$ & & & & & \\
\hline $\begin{array}{l}\text { Hyperarousal } \\
\text { (F) }\end{array}$ & $\begin{array}{l}r \\
p\end{array}$ & $\begin{array}{l}.588 \\
.000\end{array}$ & $\begin{array}{l}.419 \\
.000\end{array}$ & $\begin{array}{l}.781 \\
.000\end{array}$ & $\begin{array}{l}.688 \\
.000\end{array}$ & $\begin{array}{l}.425 \\
.000\end{array}$ & & & & \\
\hline $\begin{array}{l}\text { Washing hands } \\
\text { (G) }\end{array}$ & $r$ & $\begin{array}{l}.169 \\
.000\end{array}$ & $\begin{array}{l}.297 \\
.000\end{array}$ & $\begin{array}{l}.317 \\
.000 \\
\end{array}$ & $\begin{array}{l}.360 \\
.000 \\
\end{array}$ & $\begin{array}{l}.135 \\
.004\end{array}$ & $\begin{array}{l}.337 \\
.000 \\
\end{array}$ & & & \\
\hline Handshake (H) & $\begin{array}{l}r \\
p\end{array}$ & $\begin{array}{l}-.126 \\
.007\end{array}$ & $\begin{array}{r}-.166 \\
.000\end{array}$ & $\begin{array}{l}-.196 \\
.000\end{array}$ & $\begin{array}{r}-.202 \\
.000\end{array}$ & $\begin{array}{l}-.076 \\
.103\end{array}$ & $\begin{array}{l}-.220 \\
.000\end{array}$ & $\begin{array}{r}-.321 \\
.000\end{array}$ & & \\
\hline $\begin{array}{l}\text { Cleaning } \\
\text { materials (I) }\end{array}$ & $\begin{array}{l}r \\
p\end{array}$ & $\begin{array}{l}.204 \\
.000\end{array}$ & $\begin{array}{l}.175 \\
.000\end{array}$ & $\begin{array}{l}.262 \\
.000\end{array}$ & $\begin{array}{l}.266 \\
.000\end{array}$ & $\begin{array}{l}.141 \\
.002\end{array}$ & $\begin{array}{l}.263 \\
.000\end{array}$ & $\begin{array}{l}.372 \\
.000\end{array}$ & $\begin{array}{l}-.268 \\
.000\end{array}$ & \\
\hline $\begin{array}{l}\text { Avoiding } \\
\text { contact with } \\
\text { people }(\mathrm{K})\end{array}$ & $\begin{array}{l}r \\
p\end{array}$ & $\begin{array}{l}.173 \\
.000\end{array}$ & $\begin{array}{l}.245 \\
.000\end{array}$ & $\begin{array}{l}.273 \\
.000\end{array}$ & $\begin{array}{l}.278 \\
.000\end{array}$ & $\begin{array}{l}.159 \\
.001\end{array}$ & $\begin{array}{l}.259 \\
.000\end{array}$ & $\begin{array}{l}.264 \\
.000\end{array}$ & $\begin{array}{l}-.074 \\
.114\end{array}$ & $\begin{array}{l}.168 \\
.000\end{array}$ \\
\hline
\end{tabular}

their families might be infected. In studies evaluating students' anxiety levels during the COVID-19 pandemic, student anxiety was shown to be related to their place of residence, the source of parental income, whether they lived with parents, and whether a relative or acquaintance was infected with COVID-19 (12).

Students commonly experience stress during these outbreaks. In a study on medical stuents carried out during the MERS-CoV epidemic in Saudi Arabia, it was stated that, although medical students have a high estimated total stress level, medical students are less stressed than nursing and non-medical university students $(14,15,17)$. Similarly, this study showed that students focusing on areas other than nursing and healthcare had higher stress scores than medical students. Studies have shown that medical students have a more positive attitude, as they have more information about infectious diseases that cause epidemics (18, 19). We postulate hat this situation explains why the stress levels of non-medical students are higher than those of medical students.

In our study, an increase in cleaning and social-avoidance behaviors, especially handwashing, was observed among students. A study conducted among Korean university students during the H1N1 pandemic showed an increase in handwashing compared to the year prior (20). In a study conducted by Aker et al., $86.7 \%$ of university students saw frequent handwashing as the most important method of protection against COVID-19 (21). In another study, the majority of students stated that the first line of defense against the COVID-19 pandemic was regular handwashing, social-isolation strategies, and advanced personalhygiene measures (22). In addition, as anxiety levels and the impact of the event increased, an increase was observed in cleaning and social behavior adjustment In the study conducted by AlRabiaah et al., the stress level scores and anxiety scores correlated significantly with each other, and both the stress level scores and anxiety scores were associated with social avoidance and a change of cleaning habits (14). Similarly, another study showed that there were significant changes in healthcare workers' compliance with hand hygiene and universal precautions (for example, wearing masks and gloves) during the COVID-19 pandemic, and there was a decrease in social visits, handshake habits, and the use of public facilities (23). Consequently, anxiety over and fear of pandemic situations can affect the behavior of individuals. Anxiety over becoming infected with COVID-19, given the evident global effects, may prompt individuals to adopt preventative behaviors (24, 25).

It was observed that our student group used the internet and social media as sources of information about the COVID-19 pandemic. Studies in the literature indicate that participants report using various media types to gain information about the COVID-19 pandemic; the most-used media types are social media and the internet, followed by television and newspapers $(16,18,26)$. This shows that the young population is comfortable accesing these media types, and it is possible to communicate with young people through social media and the internet to change social behaviors to prevent outbreaks.

\section{Limitations}

As far as we know, this study began investigating the effects of anxiety and stress on university students before COVID-19 was detected 
in Turkey. However, our research is limited by its cross-sectional structure and lacks longitudinal tracking. Finally, the research reachs only students within our university, and its voluntary nature may have led to selection bias. The participants also may not represent the entire population.

\section{CONCLUSION}

Anxiety and stress caused by infectious diseases and pandemics surrounding the world affect human behavior and society. This study started when there were no cases in our country yet and ended in the days when the cases started to appear. The results of the study are important in terms of showing the anxiety and stress it creates on people even at this point. In order to guide social behavior and take necessary precautions in the management of pandemic diseases, it is necessary to carry out such studies with more working groups during various periods of this pandemic.

\section{REFERENCES}

1. World Health Organization. Coronavirus disease (COVID-19) [Internet]. [cited 2020 Jul 25]. Available from: https://www.who.int/emergencies/diseases/novel-coronavirus-2019/events-as-they-happen

2. World Health Organization. WHo director- General's opening remaks at the media briefing on Covid-19 [Internet]. [cited 2020 Jul 25]. Available from: https://www.who.int/dg/speeches/detail/who-directorgeneral-s-opening-remarks-at-the-media-briefing-on-covid-19---11-march-2020

3. Zhu N, Zhang D, Wang W, Li X, Yang B, Song J, et al. A novel coronavirus from patients with pneumonia in China, 2019. N Engl J Med. 2020;382(8):727-733.

4. Yükseköğretim kurulu. Koronavirus (COVID-19) bilgilendirme notu:1; 13 Mart [Internet]. [cited 2020 Nov 30]. Available from: https://www.yok.gov.tr/Sayfalar/Haberler/2020/coronavirus_bilgilendirme_1.aspx

5. Wang ZH, Yang HL, Yang YQ, Liu D, Li ZH, Zhang XR, et al. Prevalence of Anxiety and Depression symptom, and the Demands for Psychological Knowledge and Interventions in college students during COVID-19 epidemic: A large Cross-Sectional Study. J Affect Disord. 2020;275: 188-193

6. International Medical Corps Sierra. Assessment of mental health and psychosocial support (MHPSS) needs and resources in the context of ebola. 2014

7. Park JH, Cheong HK, Son DY, Kim SU, Ha CM. Perceptions and behaviors related to hand hygiene for the prevention of H1N1 influenza transmission among Korean university students during the peak pandemic period. BMC Infect Dis. 2020;10(1): 222.

8. Lau JT, Griffiths S, Choi KC, Tsui HY. Widespread public misconception in the early phase of the H1N1 influenza pandemic. J Infect. 2009;59(2):122-7

9. Mei SL, Yu JX, He BW, Li JY. Psychological investigation of university students in a university in Jilin Province. Medicine and Society. 2011;24(05):84-6.

10. Konkan R, Şenormancı Ö, Güçlü O, Aydın E, Sungur MZ. Yaygın Anksiyete Bozukluğu 7 (YAB-7) Testi Türkçe uyarlaması, geçerlik ve güvenirliği. Archives of Neuropsychiatry/Noropsikiatri Arsivi. 2013;50(1):53-59

11. Çorapçığlu A, Yargıç İ, Geyran P, Kocabaşoğlu N. Olayların etkisi ölçeği. InIES-R) Türkçe versiyonunun geçerlilik ve güvenilirliği. Yeni Symposium. 2006;44:14-22.

12. Cao W, Fang Z, Hou G, Han M, Xu X, Dong J, Zheng J. The psychological impact of the COVID-19 epidemic on college students in China. Psychiatry Res. 2020:112934.

13. Savitsky B, Findling Y, Ereli A, Hendel T. Anxiety and coping strategies among nursing students during the Covid-19 pandemic. Nurse Education in Practice. 2020:102809.

14. Al-Rabiaah A, Temsah MH, Al-Eyadhy AA, Hasan GM, Al-Zamil F, Al-Subaie S, et al. Middle East Respiratory Syndrome-Corona Virus (MERS-CoV) associated stress among medical students at a university teaching hospital in Saudi Arabia. Journal of infection and public health. 2020;13(5): 687-691

15. Wong JG, Cheung EP, Cheung V, Cheun, C, Chan MT, Chua SE, et al. Psychological responses to the SARS outbreak in healthcare students in Hong Kong. Medical teacher, 2004;26(7):657-659.

16. Bergeron SL, Sanchez AL. Media effects on students during SARS outbreak. Emerg Infect Dis. 2005;11(5):732.

17. Loh LC, Ali AM, Ang TH, Chelliah A. Impact of a spreading epidemic on medical students. Malays J Med Sci. 2005;12(2):43.

18. Tork HM, Mersal FA. Middle East Respiratory Syndrome-Corona virus: Knowledge and attitude of Qassim University students, KSA. Global Adv Res J Med Med Sci. 2018;7(4):90-7.

19. Khan MU, Shah S, Ahmad A, Fatokun O. Knowledge and attitude of healthcare workers about middle east respiratory syndrome in multispecialty hospitals of Qassim, Saudi Arabia. BMC Public Health. 2014;14(1):1-7.

20. Park JH, Cheong HK, Son DY, Kim SU, Ha CM. Perceptions and behaviors related to hand hygiene for the prevention of H1N1 influenza transmission among Korean university students during the peak pandemic period. BMC Infect Dis. 2020;10(1): 222.

21. Aker S, Midık Ö. The views of medical faculty students in Turkey concerning the COVID-19 pandemic. J Community Health. 2020;45(4):684-688. 
22. Khasawneh AI, Humeidan AA, Alsulaiman JW, Bloukh S, Ramadan M, Al-Shatanawi TN, et al. Medical students and COVID-19: knowledge, attitudes, and precautionary measures. A descriptive study from Jordan. Front Public Health. 2020;8:253.

23. Bukhari EE, Temsah MH, Aleyadhy AA, Alrabiaa AA, Alhboob AA, Jamal AA, et al. Middle East respiratory syndrome coronavirus (MERS-CoV) outbreak perceptions of risk and stress evaluation in nurses. The Journal of Infection in Developing Countries. 2016;10(08):845-50.

24. Roy D, Tripathy S, Kar SK, Sharma N, Verma SK, Kaushal V. Study of knowledge, attitude, anxiety \& perceived mental healthcare need in Indian population during COVID-19 pandemic. Asian J Psychiatry 2020;51:102083.

25. Torales J, O'Higgins M, Castaldelli-Maia JM, Ventriglio A. The outbreak of COVID-19 coronavirus and its impact on global mental health. Int J Soc Psychiatry 2020;66:317-320.

26. Nemati M, Ebrahimi B, Nemati F. Assessment of Iranian nurses' knowledge and anxiety toward COVID19 during the current outbreak in Iran. Arch Clin Infect Dis. 2020;15:COVID-19. 